\title{
Solution and Solid State Studies of Urea Derivatives of DITIPIRAM Acting as Powerful Anion Receptors
}

\author{
Patryk Niedbała (D), Kajetan Dąbrowa (D), Agnieszka Cholewiak-Janusz and Janusz Jurczak *D \\ Institute of Organic Chemistry Polish Academy of Sciences, Kasprzaka 44/52, 01-224 Warsaw, Poland; \\ pniedbala@icho.edu.pl (P.N.); kdabrowa@icho.edu.pl (K.D.); cholewiakagnieszka@gmail.com (A.C.-J.) \\ * Correspondence: jurczak_group@icho.edu.pl
}

\begin{abstract}
Herein, we present the synthesis and anion binding studies of a family of homologous molecular receptors 4-7 based on a DITIPIRAM (8-propyldithieno-[3,2-b:2', 3'-e]-pyridine-3,5-diamine) platform decorated with various urea para-phenyl substituents $\left(\mathrm{NO}_{2}, \mathrm{~F}, \mathrm{CF}_{3}\right.$, and $\left.\mathrm{Me}\right)$. Solution, X-ray, and DFT studies reveal that the presented host-guest system offers a convergent array of four urea $\mathrm{NH}$ hydrogen bond donors to anions allowing the formation of remarkably stable complexes with carboxylates (acetate, benzoate) and chloride anions in solution, even in competitive solvent mixtures such as DMSO- $d_{6} / \mathrm{H}_{2} \mathrm{O} 99.5 / 0.5(v / v)$ and DMSO- $d_{3} / \mathrm{MeOH}-d_{3}$ 9:1 $(v / v)$. The most effective derivatives among the series turned out to be receptors 5 and $\mathbf{6}$ containing electron-withdrawing $\mathrm{F}$ - and $-\mathrm{CF}_{3}$ para-substituents, respectively.
\end{abstract}

Keywords: anion recognition; acyclic receptors; supramolecular chemistry; DITIPIRAM

Citation: Niedbała, P.; Dąbrowa, K.; Cholewiak-Janusz, A.; Jurczak, J. Solution and Solid State Studies of Urea Derivatives of DITIPIRAM Acting as Powerful Anion Receptors. Molecules 2021, 26, 1788. https:// doi.org/10.3390/molecules26061788

Academic Editor: Borys Osmialowski

Received: 26 February 2021

Accepted: 19 March 2021

Published: 22 March 2021

Publisher's Note: MDPI stays neutral with regard to jurisdictional claims in published maps and institutional affiliations.

Copyright: (c) 2021 by the authors. Licensee MDPI, Basel, Switzerland. This article is an open access article distributed under the terms and conditions of the Creative Commons Attribution (CC BY) license (https:// creativecommons.org/licenses/by/ $4.0 /)$.

\section{Introduction}

For over twenty years, many groups working in the field of supramolecular chemistry have made substantial efforts to restore the parity between the molecular chemistry of anions and cations. As a result, many monographic studies and literature reviews have been published [1-16]. Still, the design and synthesis of receptors capable of strong and selective binding of negatively charged molecules is an essential problem considering the great role that anions play in many biological and chemical processes. Moreover, binding of anions using receptors with precisely selected properties opens the way to many important applications in medicine, pharmacy, catalysis, or transport processes [17-29]. Despite the high demand for the above-mentioned hosts for anions, numerous studies, and the development of computational techniques, the prediction of the binding properties of artificial hosts is still not a trivial task, sometimes even impossible when the anionic guest is chiral. It is, therefore, necessary to perform their synthesis and then time-consuming and expensive measurements.

Despite the shortage of basic research aimed at defining factors affecting both the efficiency and the selectivity of binding of anions, there are some useful rules that can be collected based on the previous studies. First of all, neutral anion receptors have generally an advantage over the positively charged systems due to their much higher selectivity, despite the lower stabilities of receptor-anion complexes. These result from the presence of binding groups such as hydrogen bond donors, which allow for the establishment of highly directional interactions with the anion [30-36]. Furthermore, the unquestionable advantage of acyclic receptors, compared to their cyclic analogues, is their relatively simpler synthesis due to the lack of a problematic and low-yielding macrocyclization step. Additionally, the structure of acyclic receptors is generally tunable, allowing facile post-functionalization (to increase the binding affinity or to modify selectivity) compared to macrocyclic architectures. Among other factors, this turned researchers' attention to the acyclic systems in the molecular recognition of anions [37-40]. 
In designing non-macrocyclic receptors, one should take into consideration the correlation between the rigidity of the central unit (platform) and the efficiency of the anion binding process. Moreover, very often, small changes in the structure of the receptor's binding site have a significant effect on the receptor's anion binding properties. In addition, symmetry of the receptor is as crucial as the rest of the factors defining its structure. Receptors with C2 symmetry are very efficient when binding anions such as Y-shaped carboxylates, spherical halides, or tetrahedral phosphates. Simultaneous study of both the anion binding properties and structural modifications of the host-guest complexes allows for deeper understanding of the mechanisms controlling the anion recognition phenomenon, however, it is still necessary to apply the iterative synthetic approach due to the complex relationship between the structure and anion binding properties of the designed artificial systems.

Considering the above-mentioned conditions, 8-propyldithieno [3,2-b:2', $3^{\prime}$-e]pyridine3,5-diamine (DITIPIRAM) (1) fits perfectly to the role of the platform for designing potent acyclic receptors for anions (Figure 1).<smiles>CCCc1c2scc(N)c2nc2c(N)csc12</smiles>

Figure 1. Structure of the 8-propyldithieno [3,2-b:2', $3^{\prime}$-e]pyridine-3,5-diamine (DITIPIRAM) platform.

This unique building block was recently introduced by us into supramolecular chemistry [41]. Utilization of DITIPIRAM provides a highly preorganized geometry of anion binding sites for the design of acyclic receptors decorated with functionalized urea arms. Our results proved DITIPIRAM to be an excellent choice as a platform for putative anion receptors.

\section{Results and Discussion}

In our recent study [41] with model urea receptors incorporating the DITIPIRAM building block, we showed significantly higher efficiency in anion binding by the receptor with phenyl substituents $\mathbf{3}$ compared to that with analogue $\mathbf{2}$ decorated with butyl substituents (Figure 2).

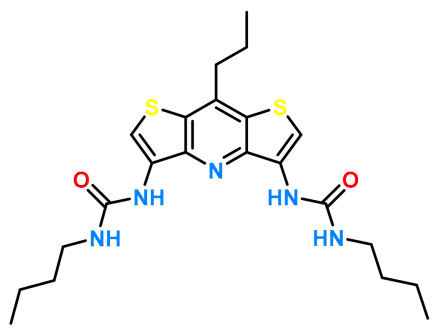

2

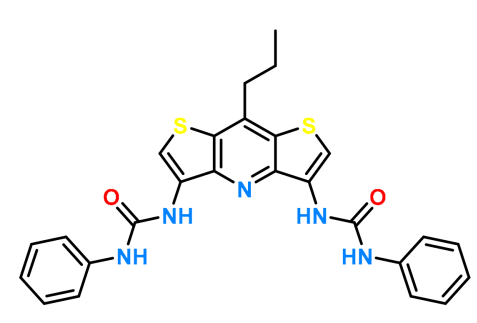

3

Figure 2. Structures of receptors 2 and 3.

In the present publication, we decided to extend our research on the anion recognition properties of molecular receptors built on the DITIPIRAM platform. Here, we investigated the impact of the aromatic substituents on the anion binding affinity and selectivity of novel analogs.

To analyze the influence of this change, it was necessary to limit our research to two variables, i.e., modification of the size and electron properties of the para-substituent relative to the urea group by using various groups with electron withdrawing (EWG) and 
electron donating (EDG) characters. Different substitution patterns could introduce, among other effects, steric hindrance, which might inhibit the binding of anions in the receptors' gap, and thus the impact of substituents would be impossible to elucidate.

The designed receptors were prepared as described in Scheme 1 . In each case, the synthesis of aromatic urea receptors containing the DITIPIRAM core included the use of 8-propyldithieno[3,2-b:2', $3^{\prime}$-e]pyridine-3,5-diamine dichydrochloride $(\mathbf{1} \times 2 \mathrm{HCl})$, triethylamine, and the corresponding isocyanate. For details see the Materials and Methods section.
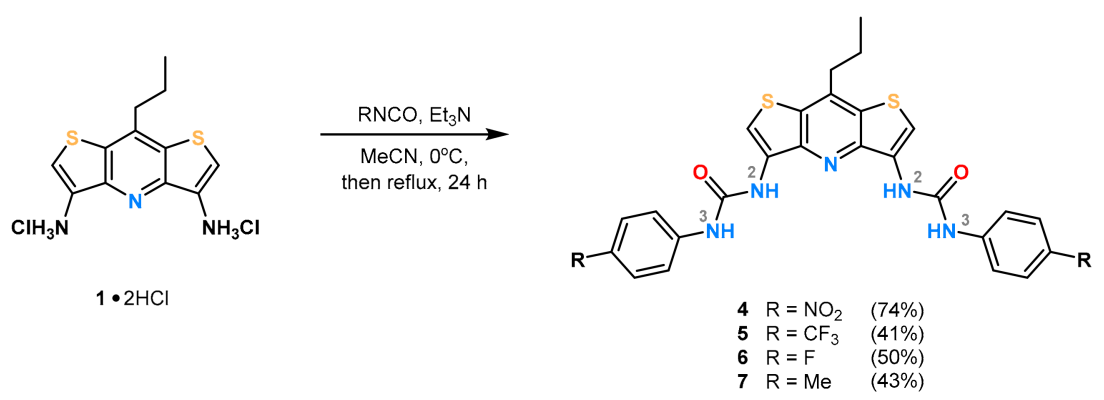

Scheme 1. Synthesis of acyclic receptors 4-7 varying in para-substituent (R) on the aryl rings.

Subsequently, we tested the binding properties of receptors 5-7 using ${ }^{1} \mathrm{H}-\mathrm{NMR}$ titration experiments, keeping the concentration of the receptor $\left(\sim 10^{-2} \mathrm{M}\right)$ constant. Unfortunately, receptor 4 turned out to be insoluble in the tested solvent, preventing the determination of its binding properties. Thankfully, the rest of receptors readily dissolved in the studied solvent mixtures (DMSO- $d_{6}$, DMSO- $d_{6} / \mathrm{H}_{2} \mathrm{O} 99.5 / 0.5 v / v$ and DMSO- $d_{6} / \mathrm{CD}_{3} \mathrm{OH}$ 9:1 $\mathrm{v} / \mathrm{v}$ ). The highest solubility was exhibited by receptors 5 and 6 equipped with trifluoromethyl and fluorine substituents, respectively. As model anionic guests, we selected chloride $\left(\mathrm{Cl}^{-}\right)$as the model spherical guest $\left(\mathrm{pK} K_{\mathrm{a}, \mathrm{H} 2 \mathrm{O}}<1\right)$, acetate $\left(\mathrm{MeCO}_{2}{ }^{-}, \mathrm{pK} K_{\mathrm{a}, \mathrm{H} 2 \mathrm{O}}=4.76\right)$ and benzoate $\left(\mathrm{PhCO}_{2}{ }^{-}, \mathrm{pK}, \mathrm{a}, \mathrm{H} 2 \mathrm{O}=4.20\right)$ as Y-shaped carboxylates with a geometry match to the urea group, and dihydrogen phosphate $\left(\mathrm{H}_{2} \mathrm{PO}_{4}{ }^{-}, \mathrm{pK} K_{\mathrm{a}, \mathrm{H} 2 \mathrm{O}}=2.14\right)$, as both a donor and acceptor of hydrogen bonds. This set of anions is routinely employed in anion recognition studies. All anions were added as corresponding salts with a bulky and diffused tetrabutylammonium (TBA) cation to ensure complete dissolution of salt and to limit the eventual impact of cations on the molecular recognition process by synthetized receptors. In general, the addition of anion aliquots caused substantial shifts of the signal of urea $\mathrm{NH}$ and aryl $\mathrm{CH}$ protons and the binding isotherms were fitted using a 1:1 (host/guest) binding model. However, in the case of the $\mathrm{H}_{2} \mathrm{PO}_{4}{ }^{-}$guest, the binding isotherm could not be fitted to either 1:1 or 2:1 anion/receptor binding models, suggesting proton transfer processes such as deprotonation of the bound anionic species by aliquots of free $\mathrm{H}_{2} \mathrm{PO}_{4}{ }^{-}$[42]. Despite the fact that it was not possible to fit the data from ${ }^{1} \mathrm{H}$-NMR titrations with dihydrogenphosphate to any tested models, the experiments clearly indicated the strong binding of $\mathrm{H}_{2} \mathrm{PO}_{4}{ }^{-}$with receptors 5-7.

The results from the performed titrations are collected in Table 1 along with the data for parent receptor 3 for comparison [43].

The data presented in Table 1 demonstrate that receptors tend to bind tested anions with high affinity and show the expected selectivity for $\mathrm{MeCO}_{2}{ }^{-}$over $\mathrm{PhCO}_{2}{ }^{-}$and $\mathrm{Cl}^{-}$. The stability constants for complexes 3 and 5-7 with carboxylates in a highly competitive DMSO- $d_{6}+0.5 \% \mathrm{H}_{2} \mathrm{O}(v / v)$ solvent mixture were too high to be determined accurately using the ${ }^{1} \mathrm{H}-\mathrm{NMR}$ titration technique $\left(\mathrm{K}>10,000 \mathrm{M}^{-1}\right)$, and an even more competitive solvent mixture (DMSO- $d_{6}+10 \% \mathrm{CD}_{3} \mathrm{OH} v / v$ ) was employed to determine their binding properties. In these solvents mixtures the receptors have to compete with water and methanol (added in large excess to the receptor) for anion binding. In addition, DMSO is a strong hydrogen bond acceptor, able to interact strongly with receptor urea $\mathrm{NH}$ protons (as well as water and methanol solvents). 
Table 1. Stability constants $\mathrm{K}_{\mathrm{a}}\left(\mathrm{M}^{-1}\right)$ for 1:1 (host/guest) complexes of receptors 3 and 5-7 with anions ${ }^{a}$.

\begin{tabular}{|c|c|c|c|c|c|}
\hline Receptor & $\mathbf{R}^{\mathbf{b}}$ & Solvent System & $\mathrm{Cl}^{-}$ & $\mathrm{MeCO}_{2}^{-}$ & $\mathrm{PhCO}_{2}^{-}$ \\
\hline \multirow{2}{*}{3} & \multirow{2}{*}{$\mathrm{H}$} & DMSO- $d_{6}+0.5 \% \mathrm{H}_{2} \mathrm{O}$ & $3350 \pm 60$ & $>10,000^{c}$ & $>10,000^{\mathrm{c}}$ \\
\hline & & DMSO- $d_{6}+10 \% \mathrm{CD}_{3} \mathrm{OH}$ & $950 \pm 10$ & $4200 \pm 90$ & $1560 \pm 20$ \\
\hline \multirow{2}{*}{5} & \multirow{2}{*}{$\mathrm{CF}_{3}$} & DMSO- $d_{6}+0.5 \% \mathrm{H}_{2} \mathrm{O}$ & $3400 \pm 80$ & $>10,000^{c}$ & $>10,000^{\mathrm{c}}$ \\
\hline & & $\mathrm{DMSO}-d_{6}+10 \% \mathrm{CD}_{3} \mathrm{OH}$ & $1040 \pm 20$ & $6300 \pm 300$ & $2400 \pm 80$ \\
\hline \multirow{2}{*}{6} & \multirow{2}{*}{$\mathrm{F}$} & DMSO- $d_{6}+0.5 \% \mathrm{H}_{2} \mathrm{O}$ & $4650 \pm 250$ & $>10,000^{c}$ & $>10,000^{c}$ \\
\hline & & DMSO- $d_{6}+10 \% \mathrm{CD}_{3} \mathrm{OH}$ & $1250 \pm 20$ & $6400 \pm 300$ & $2050 \pm 40$ \\
\hline \multirow{2}{*}{7} & \multirow{2}{*}{$\mathrm{Me}$} & DMSO $-d_{6}+0.5 \% \mathrm{H}_{2} \mathrm{O}$ & $2500 \pm 50$ & $>10,000^{c}$ & n.d. ${ }^{d}$ \\
\hline & & $\mathrm{DMSO}-d_{6}+10 \% \mathrm{CD}_{3} \mathrm{OH}$ & $915 \pm 10$ & $2950 \pm 150$ & n.d. ${ }^{d}$ \\
\hline
\end{tabular}

a Determined using ${ }^{1} \mathrm{H}-\mathrm{NMR}$ titration at $298 \mathrm{~K}$ and HypNMR 2008 software for nonlinear fitting of the binding data [42]; anions added as tetrabutylammonium (TBA) salts; estimated errors $<10 \%$; each titration was performed at least twice. ${ }^{\mathrm{b}}$ Para-substituent on the aryl moiety, see Scheme $1 .{ }^{\mathrm{c}}$ Stability constants above the limit of the ${ }^{1} \mathrm{H}-\mathrm{NMR}$ titration technique $(\geq 10,000)$. ${ }^{\mathrm{d}}$ Not determined due to precipitation of the complex.

Interestingly, the differences between binding constants of $\mathrm{MeCO}_{2}{ }^{-}$vs. $\mathrm{PhCO}_{2}{ }^{-}$ $\left(K_{\mathrm{MeCO} 2-} / K_{\mathrm{PhCO} 2-}=2.6-3.1\right)$ and in particular $\mathrm{PhCO}_{2}{ }^{-}$vs. $\mathrm{Cl}^{-}\left(K_{\mathrm{PhCO} 2-} / K_{\mathrm{Cl}-}=1.6-2.3\right)$ in this solvent mixture were not as high as expected when comparing only the relative anion basicity $\left(\mathrm{MeCO}_{2}{ }^{-}>\mathrm{PhCO}_{2}{ }^{-}>\mathrm{Cl}^{-}\right)$. This suggests that a preorganized binding pocket of the DITIPIRAM platform ensures the formation of strong complexes with anions with different sizes, geometries, and basicity, and this is clearly manifested by the marginal changes, in particular for carboxylates, in the chemical shifts of urea and aryl protons after the addition of one equivalent of anionic salts (Figure 3).

a)

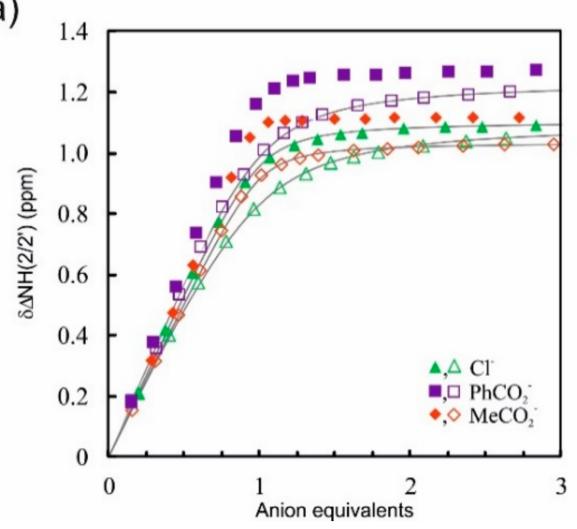

b)

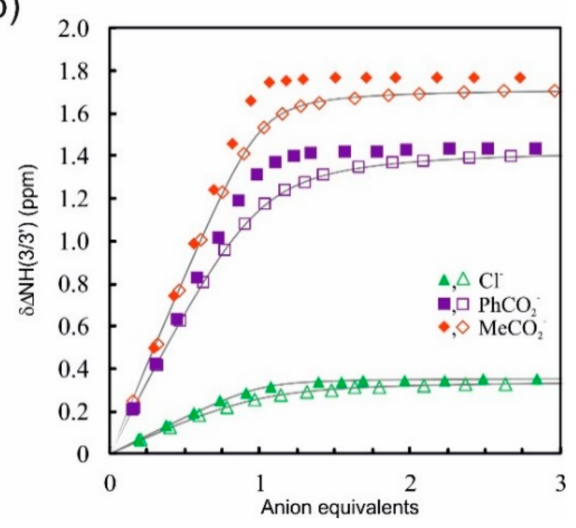

Figure 3. Representative comparison of chemical shift changes $(\Delta \delta)$ for urea protons $\mathrm{NH}\left(2 / 2^{\prime}\right)(\mathbf{a})$ and $\mathrm{NH}\left(3 / 3^{\prime}\right)(\mathbf{b})$ upon addition of $\mathrm{TBA}^{+} X^{-}\left(\mathrm{Cl}^{-}, \mathrm{PhCO}_{2}{ }^{-}, \mathrm{MeCO}_{2}{ }^{-}\right)$to the solution of 6 in DMSO- $d_{6}$ $+0.5 \% \mathrm{H}_{2} \mathrm{O}$ (closed symbols) and DMSO- $d_{6}+10 \% \mathrm{CD}_{3} \mathrm{OH}$ (open symbols); fitted binding isotherms (gray lines).

Upon addition of TBACl to the solution of receptors 3 and 5-7, the resonances of urea $\mathrm{NH}$ protons $3 / 3^{\prime}$ experienced a much smaller downfield shift compared with $\mathrm{NH}$ protons $2 / 2^{\prime}\left(\Delta \delta_{\mathrm{NH} 3-\mathrm{NH} 2}=0.74-0.84 \mathrm{ppm}\right)$. This behavior reveals that the chloride anion, which is the smallest anion among the series, interacts more strongly with urea $\mathrm{NH}$ protons $2 / 2^{\prime}$ than with protons $3 / 3^{\prime}$, whereas for larger carboxylates this difference is much less noticeable.

In addition, receptor 7 that incorporates methyl substituents shows the lowest binding affinity among the series. This might be rationalized by the decreased acidity of urea $\mathrm{NH}$ protons resulting from the transfer of electron density to the adjacent aromatic ring by the methyl group. Association constants for this receptor are even lower than for receptor 3 , which bears phenyl groups. Receptors 5 and $\mathbf{6}$, equipped with electron-withdrawing 
para-substituents (- $\mathrm{CF}_{3}$ and $-\mathrm{F}$ groups, respectively), exhibit, as expected, higher affinity toward anions than that of both receptors 3 and 7. Interestingly, however, anion binding properties of $\mathbf{5}$ and $\mathbf{6}$ are similar within the experimental error. On the basis of a simple comparison of the corresponding Hammet constants ( $\sigma_{\text {para }}=0.54$ and 0.06 for the $-\mathrm{CF}_{3}$ and -F groups, respectively), one can assume that receptor 5 should exhibit higher affinity to anions due to the stronger electron-withdrawing effect of the trifluoromethyl group.

These experimental results demonstrate that the prediction of the exact binding properties of even simple and rigid systems, as studied here for receptors $\mathbf{5}$ and $\mathbf{6}$, is still very challenging since many subtle factors have an impact on the overall binding free energy of anion-receptor complexes. It is possible the more bulky $\mathrm{CF}_{3}$ group interacts more strongly with the solvent molecules, especially with water and methanol, than with the fluorine atom, thus disturbing the solvation shell around the receptor and/or the bound anion. Nevertheless, the comparison of titration data for $\mathbf{5}$ vs. $\mathbf{6}$ indicates that receptor $\mathbf{5}$ produces a slightly stronger complex with the benzoate anion, possibly due to the stronger $\pi-\pi$ interaction between $p-\mathrm{C}_{6} \mathrm{H}_{4} \mathrm{CF}_{3}$ aryls and the phenyl of benzoate.

To further evaluate the binding properties of DITIPIRAM-based receptors, we studied the structures of the DMSO- $\mathrm{H}_{2} \mathrm{O}$ solvate of receptor 6 and its complex with chloride (added as a TBA salt). The crystals suitable for $\mathrm{X}$-ray diffraction studies were grown by a slow diffusion of water into DMSO $/ \mathrm{H}_{2} \mathrm{O}$ solutions of $\mathbf{6}$ and $\mathbf{6}$ with an excess of TBACl. Analyzing the X-ray structure of receptor $\mathbf{6}$ solvate reveals that the binding pocket of 6 is too large to accommodate $\mathrm{H}_{2} \mathrm{O}$ or DMSO molecules alone, resulting in binding of the DMSO- $\mathrm{H}_{2} \mathrm{O}$ dimer. The DMSO is located above the binding pocket, interacting with one urea arm and with a water molecule via a hydrogen bond, whereas the water molecule is localized inside the binding pocket, also forming three hydrogen bonds: two with the second urea arm of the receptor and one with a DMSO. It is notable that the receptor is preorganized to bind anions due to the favorable syn-syn conformation of the urea arms (Figure $4 a, c)$.

a)

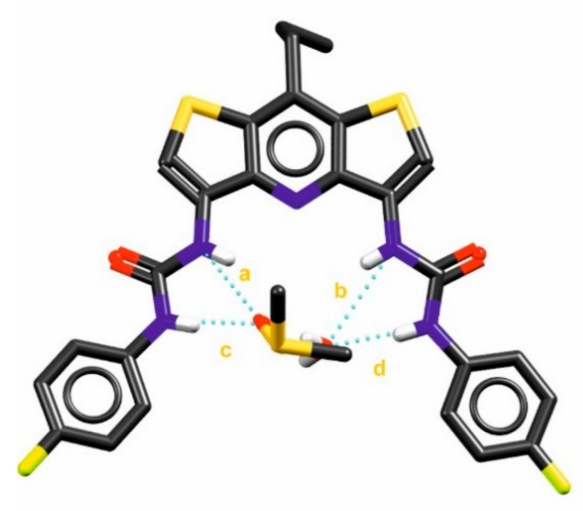

c)

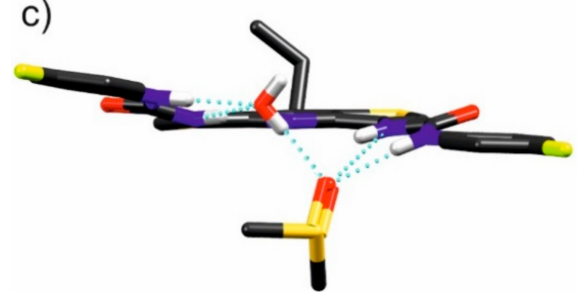

b)

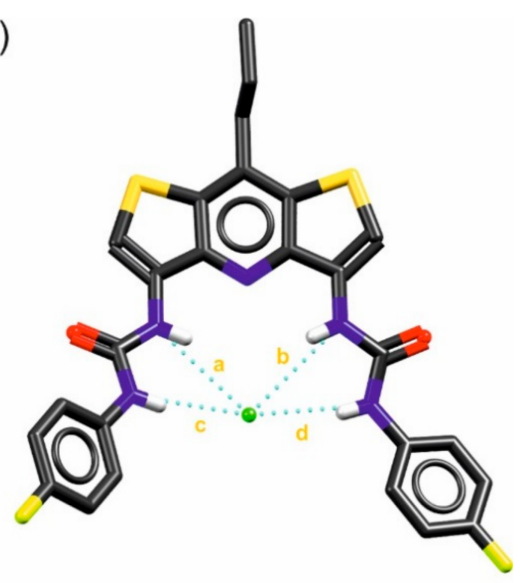

d)

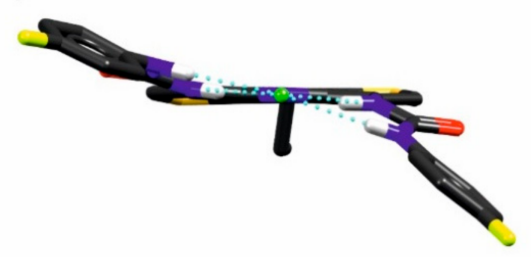

Figure 4. X-ray structures of $\mathbf{6} @\left(\mathrm{DMSO} \cdot \mathrm{H}_{2} \mathrm{O}\right)$ solvate $(\mathbf{a}, \mathbf{c})$ and the $\mathbf{6} @(\mathrm{Cl})$ TBA anionic complex $(\mathbf{b}, \mathbf{d})$. Non-acidic protons and disorder were omitted for clarity; the hydrogen bonds are shown as dashed blue lines. For hydrogen bond lengths (a-d), see the inset table in Figure 5. 
The X-ray structure of the chloride complex with receptor 6 reveals that the receptor interacts strongly with this anionic guest by means of all four available urea NH hydrogen bonds. The chloride anion is located at the center of the binding site, confirming the great complementarity of the receptors' binding pocket to anions. The urea arms are in syn-syn conformation, which enables a comparative binding of the two urea groups (Figure $4 b, d$ ).

Comparing the individual lengths of the hydrogen bonds and the distances shown in Figure 5 and Table 2, it may be noted that despite the very similar geometry and size of the binding pocket (compare the distances marked with the letters $y$ and $z$ in the mentioned figure), in the case of complexation of the water and DMSO molecules, the urea arms of receptor $\mathbf{6}$ expand to a greater extent than they do in chloride anion bonding. The distances between the urea nitrogen atoms adjacent to the $p$-fluorophenyl substituents differ for both complexes by as much as $0.58 \AA$ despite the evident similarity between these structures (Figure 5b).

a)

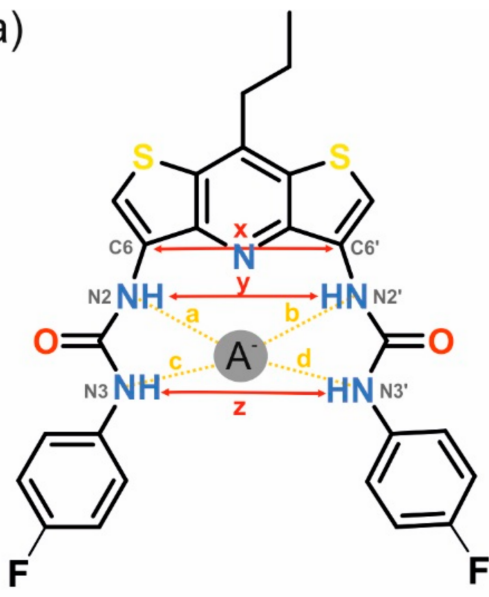

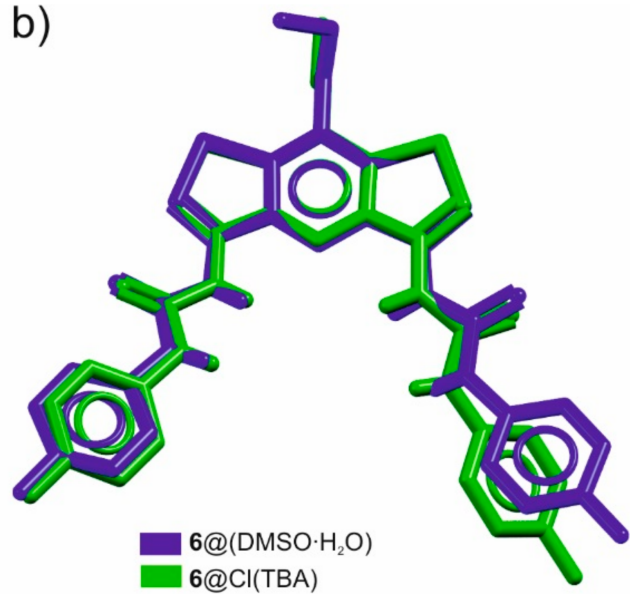

Figure 5. Geometrical descriptors of the binding pocket of the DITIPIRAM-based receptor 6 (a), superposition of crystal structures of $\mathbf{6} \cdot\left(\mathrm{DMSO} \cdot \mathrm{H}_{2} \mathrm{O}\right)$ solvate (colored in blue) and $\mathbf{6} \cdot \mathrm{TBACl}$ (colored in green) (b).

Table 2. Exact distances $\mathrm{x}, \mathrm{y}, \mathrm{z}$ and a-d describing the discussed structures.

\begin{tabular}{|c|c|c|c|c|c|c|c|}
\hline \multirow{2}{*}{ Scheme } & \multicolumn{3}{|c|}{ Geometrical Descriptors (Å) } & \multicolumn{4}{|c|}{ Hydrogen Bond Lengths (Å) } \\
\hline & $\mathbf{x}$ & $\mathbf{y}$ & $\mathbf{z}$ & $\mathbf{a}$ & $\mathbf{b}$ & c & d \\
\hline 6. $\left(\mathrm{DMSO} \cdot \mathrm{H}_{2} \mathrm{O}\right)$ & 4.89 & 5.11 & 7.12 & 3.18 & 3.19 & 2.84 & 2.83 \\
\hline $6 \cdot \mathrm{TBACl}^{\mathrm{a}}$ & 4.82 & 4.87 & 6.54 & 3.39 & 3.46 & 3.29 & 3.30 \\
\hline $\begin{array}{c}\text { Difference } \\
\text { solvate-complex }(\AA)\end{array}$ & 0.07 & 0.24 & 0.58 & -0.21 & -0.27 & -0.45 & -0.47 \\
\hline
\end{tabular}

a Two nonequivalent structures of complexes exist in the crystal cell; the parameters for conformer \#1 are given, see SI for details.

Comparing the lengths of the $\mathrm{NH}^{-. . \mathrm{Cl}^{-}}$hydrogen bonds (a-b vs. $\mathrm{c}-\mathrm{d}$ ) in the crystal structure of $6 \cdot \mathrm{TBACl}$ (Figure 5, Table 2) with the shift changes of urea NH protons $\left(2 / 2^{\prime}\right.$ vs. $3 / 3^{\prime}$ ) upon addition of TBACl to a solution of receptor (Figure 3 ) it could be noticed that host 6 , binding the chloride anion, behaves differently in solution than in a solid state. Specifically, in solution, the NH protons $\left(2 / 2^{\prime}\right)$ are involved in stronger interactions with the anion as compared to with the protons $\left(3 / 3^{\prime}\right)$, whereas the opposite situation occurs in the solid state, i.e., the lengths of the hydrogen bonds $a-b$ are longer than with $c-d$, indicating a weaker interaction. This seemingly contradictory result could be attributed to the crystal packing forces that do not allow the chloride anion to enter too deeply inside the binding pocket [43].

To achieve better insights into the binding mode of receptors $2-7$ toward anions in solution, we performed DFT calculations using M06-2X combined with a 6-31G(d) basis set 
and C-PCM model (DMSO, $\varepsilon=46.83$ ) to approximate the solvent effects. The superposition of energy-minimized conformations of receptors and their complexes with $\mathrm{Cl}^{-}, \mathrm{MeCO}_{2}{ }^{-}$, and $\mathrm{PhCO}_{2}{ }^{-}$along with the average geometrical parameters and lengths of hydrogen bond interactions in the complexes are demonstrated in Figure 6.

(a)

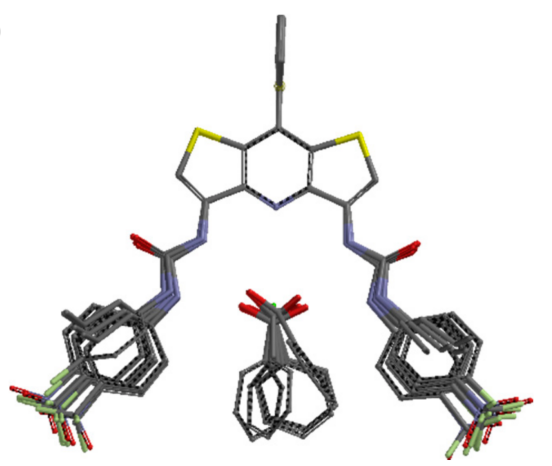

(b)

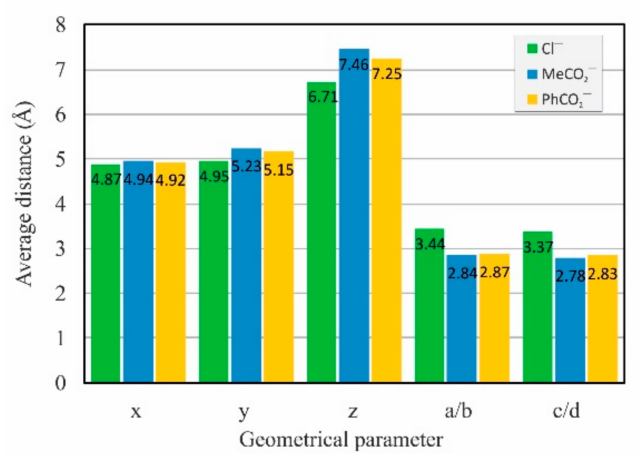

Figure 6. Superposition of DFT-calculated structures of receptors 2-7 and their complexes with chloride, acetate, and benzoate exemplifies the high preorganization of the DITIPIRAM moiety (a) and average values of geometrical parameters describing anion complexes (b); see Figure 5a for labels.

The results of DFT calculations are in line with the experimental data from the solution and solid state, showing that molecular receptors based on the DITIPIRAM platform provide well-preorganized binding sites for anion recognition. In addition, only minimal structural rearrangement of the receptor conformation is necessary prior to anion binding.

\section{Materials and Methods}

\subsection{Reagents and General Methods}

All reagents were used as received. The solvents were dried by distillation over the appropriate drying agents. All solvents were obtained from common suppliers and used as received. TLC was carried out on Merck Kieselgel F254 plates (Merck, Germany). The NMR spectra were recorded on a Bruker Mercury 400 instrument (Bruker, Ettlingen, Germany). Chemical shifts are reported in ppm $(\delta)$ and were set to the solvent residue peak. J coupling constants values are reported in Hz. Mass spectral analyses were performed with the ESITOF technique on a Mariner mass spectrometer from PerSeptive Biosystem (Waltham, MA, USA). The lowest energy conformations of the complexes of receptor 3-7 with chloride, acetate, and benzoate were found after conducting a conformational search analysis. The selected conformers with the lowest energies were then optimized without any constrains at the DFT/M06-2X/6-31G(d)/C-PCM:DMSO level of theory using program Spartan'18 Parallel Suite (see Supplementary Information for details) [44-48].

\subsection{Synthetic Procedures}

3.2.1. Synthesis of 1-(4-nitrophenyl)-3-(12-\{[(4-nitrophenyl)carbamoyl]amino\}-8-propyl6,10-dithia-2-azatricyclo[7.3.0.0 ${ }^{3}, 7$ dodeca-1,3(7),4,8,11-pentaen-4-yl)urea (4)

To a suspension of $\mathbf{1} \cdot 2 \mathrm{HCl}(0.60 \mathrm{~g}, 1.78 \mathrm{mmol})$ in $\mathrm{MeCN}(100 \mathrm{~mL})$ were added dropwise $\mathrm{Et}_{3} \mathrm{~N}(0.75 \mathrm{~mL}, 5.35 \mathrm{mmol})$ and $p$-nitrophenyl isocyanate $(0.88 \mathrm{~mL}, 5.35 \mathrm{mmol})$ at $0{ }^{\circ} \mathrm{C}$. The mixture was stirred for $8 \mathrm{~h}$ at $\mathrm{rt}$ and the solvent was evaporated off, giving the crude product that was dissolved in DMSO and precipitated with water, filtered off, washed with water $(\sim 200 \mathrm{~mL})$, and dried under vacuum to yield product $4(0.78 \mathrm{~g}, 1.32 \mathrm{mmol}, 74 \%)$ in the form of a yellow solid ( $\mathrm{mp} 257-258{ }^{\circ} \mathrm{C}$, decomposition).

${ }^{1} \mathrm{H}-\mathrm{NMR}\left(400 \mathrm{MHz}, \mathrm{DMSO}-d_{6}\right) \delta 10.33(\mathrm{~s}, 2 \mathrm{H}), 9.16(\mathrm{~s}, 2 \mathrm{H}), 8.25(\mathrm{~d}, J=9.2 \mathrm{~Hz}, 4 \mathrm{H})$, $8.14(\mathrm{~s}, 2 \mathrm{H}), 7.79(\mathrm{~d}, J=9.2 \mathrm{~Hz}, 4 \mathrm{H}), 3.14(\mathrm{t}, J=7.5 \mathrm{~Hz}, 2 \mathrm{H}), 2.0-1.81(\mathrm{~m}, 2 \mathrm{H}), 1.00(\mathrm{t}, J=7.3$ $\mathrm{Hz}, 3 \mathrm{H}) .{ }^{13} \mathrm{C}\left\{{ }^{1} \mathrm{H}\right\} \mathrm{NMR}\left(100 \mathrm{MHz}, \mathrm{DMSO}-d_{6}\right) \delta 151.8,146.6,146.1,141.2,140.3,129.4,128.1$, 
125.3, 117.4, 111.8, 34.6, 20.9, 14.0. HRMS ESI $(m / z)$ calc. for $\mathrm{C}_{26} \mathrm{H}_{21} \mathrm{~N}_{7} \mathrm{O}_{6} \mathrm{~S}_{2} \mathrm{Na}[\mathrm{M}+\mathrm{Na}]^{+}$: 614.0892, found: 614.0897. Anal (\%) calc. for $\mathrm{C}_{26} \mathrm{H}_{21} \mathrm{~N}_{7} \mathrm{O}_{6} \mathrm{~S}_{2}$.DMSO: C 50.21, H 4.06, N 14.64, found: C 50.12, H 4.23, N 14.87. IR (KBr) 3345, 3083, 2960, 1714, 1551, 1496, 1412, $1328,1212,1109,1007,949,850,749,705,610527 \mathrm{~cm}^{-1}$.

3.2.2. Synthesis of 3-[8-propyl-12-(\{[4-(trifluoromethyl)phenyl]carbamoyl\}amino)-6,10dithia-2-azatricyclo[7.3.0.03,, ]dodeca-1,3(7),4,8,11-pentaen-4-yl]-1-[4(trifluoromethyl)phenyl]urea (5)

To a suspension of $\mathbf{1} \cdot 2 \mathrm{HCl}(0.60 \mathrm{~g}, 1.78 \mathrm{mmol})$ in $\mathrm{MeCN}(100 \mathrm{~mL})$ were added dropwise $\mathrm{Et}_{3} \mathrm{~N}(0.75 \mathrm{~mL}, 5.35 \mathrm{mmol})$ and $p$-(trifluoromethyl)phenyl isocyanate $(0.75 \mathrm{~mL}, 5.35 \mathrm{mmol})$ at $0{ }^{\circ} \mathrm{C}$. The mixture was stirred for $12 \mathrm{~h}$ in $\mathrm{rt}$ and the solvent was evaporated, giving the crude product that was recrystallized from EA and yielded after drying under vacuum product 5 ( $0.47 \mathrm{~g}, 0.74 \mathrm{mmol}, 41 \%)$ in the form of a colorless solid (mp 287-288 ${ }^{\circ} \mathrm{C}$, decomposition).

${ }^{1} \mathrm{H}-\mathrm{NMR}\left(400 \mathrm{MHz}, \mathrm{DMSO}-d_{6}\right) \delta 10.02(\mathrm{~s}, 2 \mathrm{H}), 9.06(\mathrm{~s}, 2 \mathrm{H}), 8.11(\mathrm{~s}, 2 \mathrm{H}), 7.73$ (dd, $J=29.8,8.7 \mathrm{~Hz}, 8 \mathrm{H}), 3.13(\mathrm{t}, J=7.5 \mathrm{~Hz}, 2 \mathrm{H}), 2.02-1.81(\mathrm{~m}, 2 \mathrm{H}), 1.00(\mathrm{t}, J=7.3 \mathrm{~Hz}, 3 \mathrm{H})$. ${ }^{13} \mathrm{C}\left\{{ }^{1} \mathrm{H}\right\}$ NMR $\left(100 \mathrm{MHz}, \mathrm{DMSO}-d_{6}\right) \delta 152.1,146.6,143.3,140.3,129.7,128.1,126.24(\mathrm{~d}, J$ $=3.2 \mathrm{~Hz}), 124.5\left(\mathrm{CF}_{3}, \mathrm{q}, J=271.1 \mathrm{~Hz}\right), 122.0(\mathrm{q}, J=31.5 \mathrm{~Hz}), 117.7,110.6,34.6,20.9,14.00$. HRMS ESI $(m / z)$ calc. for $\mathrm{C}_{28} \mathrm{H}_{21} \mathrm{~F}_{6} \mathrm{~N}_{5} \mathrm{O}_{2} \mathrm{~S}_{2} \mathrm{Na}[\mathrm{M}+\mathrm{Na}]^{+}: 660.0939$, found: 660.0931. Anal (\%) calc. for $\mathrm{C}_{28} \mathrm{H}_{21} \mathrm{~F}_{6} \mathrm{~N}_{5} \mathrm{O}_{2} \mathrm{~S}_{2} \cdot \mathrm{H}_{2} \mathrm{O}$ : C 51.29, H 3.54, N 10.68, found: C 51.13, H 3.45, N 10.66. IR (KBr) 3653, 3302, 3089, 2962, 1906, 1711, 1674, 1607, 1563, 1411, 1362, 1320, 1166, $1114,863,689,507 \mathrm{~cm}^{-1}$.

3.2.3. Synthesis of 1-(4-fluorophenyl)-3-(12-\{[(4-fluorophenyl)carbamoyl]amino\}-8-propyl6,10-dithia-2-azatricyclo[7.3.0.0 ${ }^{3}$, ]dodeca-1,3(7),4,8,11-pentaen-4-yl)urea (6)

To a suspension of $\mathbf{1} \cdot 2 \mathrm{HCl}(0.60 \mathrm{~g}, 1.78 \mathrm{mmol})$ in $\mathrm{MeCN}(100 \mathrm{~mL})$ were added dropwise $\mathrm{Et}_{3} \mathrm{~N}(0.75 \mathrm{~mL}, 5.35 \mathrm{mmol})$ and $p$-fluorophenyl isocyanate $(0.61 \mathrm{~mL}, 5.35 \mathrm{mmol})$ at $0{ }^{\circ} \mathrm{C}$. The mixture was stirred for $12 \mathrm{~h}$ in $\mathrm{rt}$ and the solvent was evaporated, giving a crude product which was dissolved in EA $(\sim 30 \mathrm{~mL})$ and washed with water $(3 \times 30 \mathrm{~mL})$. The organic phase was dried over anhydrous $\mathrm{Na}_{2} \mathrm{SO}_{4}$, the solvent was evaporated, and the remaining residue was dried under vacuum, yielding product $6(0.48 \mathrm{~g}, 0.89 \mathrm{mmol}, 50 \%)$ in the form of a colorless solid (mp $269^{\circ} \mathrm{C}$, decomposition).

${ }^{1} \mathrm{H}-\mathrm{NMR}\left(400 \mathrm{MHz}, \mathrm{DMSO}-d_{6}\right) 9.64(\mathrm{~s}, 2 \mathrm{H}), 8.93(\mathrm{~s}, 2 \mathrm{H}), 8.04(\mathrm{~s}, 2 \mathrm{H}), 7.80-7.40(\mathrm{~m}$, $4 \mathrm{H}), 7.17(\mathrm{t}, J=8.9 \mathrm{~Hz}, 4 \mathrm{H}), 3.11(\mathrm{t}, J=7.5 \mathrm{~Hz}, 2 \mathrm{H}), 2.01-1.80(\mathrm{~m}, 2 \mathrm{H}), 0.99(\mathrm{t}, J=7.3 \mathrm{~Hz}$, 3H). ${ }^{13} \mathrm{C}\left\{{ }^{1} \mathrm{H}\right\} \mathrm{NMR}\left(100 \mathrm{MHz}, \mathrm{DMSO}-d_{6}\right)$ 158.6, 156.2, 152.4, 146.6, 140.1, 136.0, 130.0, 128.0, 119.7 (x2), 115.5, 115.3, 109.8, 34.6, 20.9, 14.0. HRMS ESI $(m / z)$ calc. for $\mathrm{C}_{26} \mathrm{H}_{21} \mathrm{~F}_{2} \mathrm{~N}_{5} \mathrm{O}_{2} \mathrm{~S}_{2} \mathrm{Na}$ $[\mathrm{M}+\mathrm{Na}]^{+}: 560.1002$, found: 560.1000. Anal (\%) calc. for $\mathrm{C}_{26} \mathrm{H}_{21} \mathrm{~F}_{2} \mathrm{~N}_{5} \mathrm{O}_{2} \mathrm{~S}_{2}$ : C 58.09, $\mathrm{H} 3.94$, N 13.03, found: C 57.47, H 3.96, N 12.59. IR (KBr) 3327, 3097, 2958, 2932, 2871, 1867, 1697, $1655,1615,1569,1532,1506,1365,1216,1099,828,786,659,514,486 \mathrm{~cm}^{-1}$.

3.2.4. Synthesis of 1-(4-methylphenyl)-3-(12-\{[(4-methylphenyl)carbamoyl]amino\}-8propyl-6,10-dithia-2-azatricyclo[7.3.0.0 ${ }^{3}, 7$ dodeca-1,3(7),4,8,11-pentaen-4-yl)urea (7)

To a suspension of $\mathbf{1} \cdot 2 \mathrm{HCl}(0.60 \mathrm{~g}, 1.78 \mathrm{mmol})$ in $\mathrm{MeCN}(100 \mathrm{~mL})$ were added dropwise $\mathrm{Et}_{3} \mathrm{~N}(0.75 \mathrm{~mL}, 5.35 \mathrm{mmol})$ and $p$-methylphenyl isocyanate $(0.67 \mathrm{~mL}, 5.35 \mathrm{mmol})$ at $0{ }^{\circ} \mathrm{C}$. The mixture was stirred for $24 \mathrm{~h}$ at $\mathrm{rt}$ and the solvent was evaporated off giving a crude product that was recrystallized from the mixture of EA and acetone. Then, the solid was filtered off and dried under vacuum yielding product $7(0.41 \mathrm{~g}, 0.77 \mathrm{mmol}, 43 \%)$ in the form of a colorless solid (mp $256-257^{\circ} \mathrm{C}$ (decomposition).

${ }^{1} \mathrm{H}-\mathrm{NMR}\left(400 \mathrm{MHz}, \mathrm{DMSO}-\mathrm{d}_{6}\right) 9.48(\mathrm{~s}, 2 \mathrm{H}), 8.91(\mathrm{~s}, 2 \mathrm{H}), 8.03(\mathrm{~s}, 2 \mathrm{H}), 7.43$ (d, J = 8.2 Hz, $4 \mathrm{H}), 7.13(\mathrm{~d}, J=8.1 \mathrm{~Hz}, 4 \mathrm{H}), 3.12(\mathrm{t}, J=7.5 \mathrm{~Hz}, 2 \mathrm{H}), 2.27(\mathrm{~s}, 6 \mathrm{H}), 2.05-1.74(\mathrm{~m}, J=14.8$, $7.3 \mathrm{~Hz}, 2 \mathrm{H}), 0.99(\mathrm{t}, J=7.3 \mathrm{~Hz}, 3 \mathrm{H}) .{ }^{13} \mathrm{C}\left\{{ }^{1} \mathrm{H}\right\}$ NMR (100 MHz, DMSO-d 6$)$ 152.3, 146.6, 140.1, 137.0, 130.8, 130.2, 129.3, 128.0, 118.1, 109.5, 34.6, 20.9, 20.3, 14.0. HRMS ESI $(m / z)$ calc. for $\mathrm{C}_{28} \mathrm{H}_{27} \mathrm{~N}_{5} \mathrm{O}_{2} \mathrm{~S}_{2} \mathrm{Na}[\mathrm{M}+\mathrm{Na}]^{+}$: 552.1504, found: 552.1507. Anal (\%) calc. for 
$\mathrm{C}_{28} \mathrm{H}_{27} \mathrm{~N}_{5} \mathrm{O}_{2} \mathrm{~S}_{2} \cdot 0.5 \mathrm{H}_{2} \mathrm{O}$ : C 62.43, H 5.24, N 13.00, found: C 62.29, H 4.80, N 12.88. IR (KBr) 3299, 3107, 2958, 2919, 2869, 1712, 1603, 1560, 1514, 1359, 1310, 1202, 1173 1045, 815, $647,508 \mathrm{~cm}^{-1}$.

\section{Conclusions}

The obtained receptors 4-7, containing a DITIPIRAM core decorated with urea-aryl tethers, constitute a class of extremely effective anion receptors. Solution studies demonstrate very high affinity of 5-7 to carboxylates (acetate, benzoate) and even much less basic chloride in demanding solvent mixtures (DMSO- $d_{6} / \mathrm{H}_{2} \mathrm{O}$ 99.5:0.5 $v / v$ and DMSO$d_{6} / \mathrm{CD}_{3} \mathrm{OH}$ 9:1 $\left.v / v\right)$. The most effective derivatives among the series turned out to be those containing electron withdrawing para-substituents: trifluoromethyl (5) and fluoride (6). Solution, X-ray, and DFT studies reveal that the binding pocket of the receptors is highly preorganized, allowing cooperative binding of anions by four hydrogen bond donor groups.

Supplementary Materials: The following are available online at https:/ /www.mdpi.com/1420-304 9/26/6/1788/s1. File 1: Copies of ${ }^{1} \mathrm{H}$ - and ${ }^{13} \mathrm{C}-\mathrm{NMR}$ spectra of all the compounds and relevant geometrical descriptors, hydrogen bond lengths, and calculated Gibbs free energies of energy-optimized complexes of receptors 2-7 with anions, $\mathrm{X}$-ray crystallographic data, and titration experiments for receptors 5-7. File 2 and File 3: checkCIF files for compound $\mathbf{6} @(\mathrm{DMSO} \cdot \mathrm{H} 2 \mathrm{O})$ and $\mathbf{6} @(\mathrm{Cl}) \mathrm{TBA}$. CCDC 2063422 and 2063423 contains the supplementary crystallographic data for this paper. These data can be obtained free of charge via www.ccdc.cam.ac.uk/data_request/cif, or by emailing data_request@ccdc.cam.ac.uk, or by contacting The Cambridge Crystallographic Data Centre, 12 Union Road, Cambridge CB2 1EZ, UK; fax: + 441223336033.

Author Contributions: Conceptualization, A.C.-J. and J.J.; methodology, A.C.-J. and J.J.; validation, P.N. and K.D.; formal analysis, A.C.-J. and P.N.; investigation, A.C.-J.; resources, J.J.; data curation, P.N. and K.D.; writing-original draft preparation, P.N., K.D., A.C.-J. and J.J.; writing—review and editing, P.N., K.D. and J.J.; visualization, P.N. and K.D.; supervision, J.J.; project administration, J.J.; funding acquisition, J.J. All authors have read and agreed to the published version of the manuscript.

Funding: This research was funded by Poland's National Science Center, grant number 2016/21/B/ ST5/03352.

Institutional Review Board Statement: Not applicable.

Informed Consent Statement: Not applicable.

Data Availability Statement: Not applicable.

Acknowledgments: We would like to acknowledge Łukasz Dobrzycki (Advanced Crystal Engineering Laboratory (aceLAB) at the Chemistry Department of the University of Warsaw).

Conflicts of Interest: The authors declare no conflict of interest.

Sample Availability: Samples of the compounds are available in limited quantity from the authors.

\section{References}

1. Pina, F.; Bernardo, M.A.; García-España, E. Fluorescent Chemosensors Containing Polyamine Receptors. Eur. J. Inorg. Chem. 2000, 2000, 2143-2157. [CrossRef]

2. Amendola, V.; Bonizzoni, M.; Esteban-Gómez, D.; Fabbrizzi, L.; Licchelli, M.; Sancenón, F.; Taglietti, A. Some guidelines for the design of anion receptors. Coord. Chem. Rev. 2006, 250, 1451-1470. [CrossRef]

3. Li, X.; Wu, Y.-D.; Yang, D. $\alpha$-Aminoxy Acids: New Possibilities from Foldamers to Anion Receptors and Channels. Acc. Chem. Res. 2008, 41, 1428-1438. [CrossRef] [PubMed]

4. Dydio, P.; Lichosyt, D.; Jurczak, J. Amide- and urea-functionalized pyrroles and benzopyrroles as synthetic, neutral anion receptors. Chem. Soc. Rev. 2011, 40, 2971-2985. [CrossRef] [PubMed]

5. Haridas, V.; Sahu, S.; Kumar, P.P.P.; Sapala, A.R. Triazole: A new motif for anion recognition. RSC Adv. 2012, 2, 12594-12605. [CrossRef]

6. Dydio, P.; Detz, R.J.; Reek, J.N.H. Precise Supramolecular Control of Selectivity in the Rh-Catalyzed Hydroformylation of Terminal and Internal Alkenes. J. Am. Chem. Soc. 2013, 135, 10817-10828. [CrossRef] 
7. Evans, N.H.; Beer, P.D. Advances in Anion Supramolecular Chemistry: From Recognition to Chemical Applications. Angezw. Chem. Int. Ed. 2014, 53, 11716-11754. [CrossRef]

8. Langton, M.J.; Serpell, C.J.; Beer, P.D. Anion Recognition in Water: Recent Advances from a Supramolecular and Macromolecular Perspective. Angew. Chem. Int. Ed. 2015, 55, 1974-1987. [CrossRef]

9. Busschaert, N.; Caltagirone, C.; Van Rossom, W.; Gale, P.A. Applications of Supramolecular Anion Recognition. Chem. Rev. 2015, 115, 8038-8155. [CrossRef]

10. Gale, P.A.; Howe, E.N.W.; Wu, X. Anion Receptor Chemistry. Chem 2016, 1, 351-422. [CrossRef]

11. Molina, P.; Zapata, F.; Caballero, A. Anion Recognition Strategies Based on Combined Noncovalent Interactions. Chem. Rev. 2017, 117, 9907-9972. [CrossRef] [PubMed]

12. He, Q.; Vargas-Zúñiga, G.I.; Kim, S.H.; Kim, S.K.; Sessler, J.L. Macrocycles as Ion Pair Receptors. Chem. Rev. 2019, 119, 9753-9835. [CrossRef]

13. Davis, J.T.; Gale, P.A.; Quesada, R. Advances in anion transport and supramolecular medicinal chemistry. Chem. Soc. Rev. 2020, 49, 6056-6086. [CrossRef]

14. Zhao, W.; Flood, A.H.; White, N.G. Recognition and applications of anion-anion dimers based on anti-electrostatic hydrogen bonds (AEHBs). Chem. Soc. Rev. 2020, 49, 7893-7906. [CrossRef]

15. Kumar, P.; Kumar, V.; Gupta, R. Dipicolinamide and isophthalamide based fluorescent chemosensors: Recognition and detection of assorted analytes. Dalton Trans. 2020, 49, 9544-9555. [CrossRef]

16. Taylor, M.S. Anion recognition based on halogen, chalcogen, pnictogen and tetrel bonding. Coord. Chem. Rev. 2020, 413, 213270. [CrossRef]

17. Malinowska, E.; Jurczak, J.; Stankiewicz, T. Macrocyclic oxamides as ionophores for lead-selective membrane electrodes. Electroanalysis 1993, 5, 489-492. [CrossRef]

18. Duke, R.M.; McCabe, T.; Schmitt, W.; Gunnlaugsson, T. Recognition and Sensing of Biologically Relevant Anions in Alcohol and Mixed Alcohol-Aqueous Solutions Using Charge Neutral Cleft-Like Glycol-Derived Pyridyl-Amidothiourea Receptors. J. Org. Chem. 2012, 77, 3115-3126. [CrossRef]

19. Lim, J.Y.C.; Marques, I.; Félix, V.; Beer, P.D. Enantioselective Anion Recognition by Chiral Halogen-Bonding [2]Rotaxanes. J. Am. Chem. Soc. 2017, 139, 12228-12239. [CrossRef]

20. Zawada, Z.; Tatar, A.; Mocilac, P.; Buděšínský, M.; Kraus, T. Transport of Nucleoside Triphosphates into Cells by Artificial Molecular Transporters. Angew. Chem. Int. Ed. 2018, 57, 9891-9895. [CrossRef]

21. Liu, W.; Oliver, A.G.; Smith, B.D. Macrocyclic Receptor for Precious Gold, Platinum, or Palladium Coordination Complexes. J. Am. Chem. Soc. 2018, 140, 6810-6813. [CrossRef] [PubMed]

22. Ji, X.; Chi, X.; Ahmed, M.; Long, L.; Sessler, J.L. Soft Materials Constructed Using Calix[4]pyrrole- and "Texas-Sized" Box-Based Anion Receptors. Acc. Chem. Res. 2019, 52, 1915-1927. [CrossRef]

23. Majdecki, M.; Niedbała, P.; Jurczak, J. Amide-Based Cinchona Alkaloids as Phase-Transfer Catalysts: Synthesis and Potential Application. Org. Lett. 2019, 21, 8085-8090. [CrossRef]

24. Borissov, A.; Marques, I.; Lim, J.Y.C.; Félix, V.; Smith, M.D.; Beer, P.D. Anion Recognition in Water by Charge-Neutral Halogen and Chalcogen Bonding Foldamer Receptors. J. Am. Chem. Soc. 2019, 141, 4119-4129. [CrossRef] [PubMed]

25. Bunchuay, T.; Docker, A.; Martinez-Martinez, A.J.; Beer, P.D. A Potent Halogen-Bonding Donor Motif for Anion Recognition and Anion Template Mechanical Bond Synthesis. Angew. Chem. Int. Ed. 2019, 58, 13823-13827. [CrossRef] [PubMed]

26. Majdecki, M.; Niedbała, P.; Jurczak, J. Synthesis of C2 Hybrid Amide-Based PTC Catalysts and Their Comparison with Saturated Analogues. Chem. Sel. 2020, 5, 6424-6429. [CrossRef]

27. Lv, S.; Li, X.; Yang, L.; Wang, X.; Zhang, J.; Zhang, G.; Jiang, J. Azopyrazole-Based Photoswitchable Anion Receptor for Dihydrogen Phosphate Transport. J. Phys. Chem. 2020, 124, 9692-9697. [CrossRef]

28. Wang, F.; Sen, S.; Chen, C.; Bähring, S.; Lei, C.; Duan, Z.; Zhang, Z.; Sessler, J.L.; Jana, A. Self-Assembled Cagelike Receptor That Binds Biologically Relevant Dicarboxylic Acids via Proton-Coupled Anion Recognition. J. Am. Chem. Soc. 2020, 142, 1987-1994. [CrossRef] [PubMed]

29. Kohnke, F.H. Calixpyrroles: From Anion Ligands to Potential Anticancer Drugs. Eur. J. Org. Chem. 2020, 4261-4272. [CrossRef]

30. Chmielewski, M.J.; Jurczak, J. A hybrid macrocycle containing benzene and pyridine subunits is a better anion receptor than both its homoaromatic congeners. Tetrahedron Lett. 2005, 46, 3085-3088. [CrossRef]

31. Zieliński, T.; Kędziorek, M.; Jurczak, J. Bisamides Derived from Azulene-1,3- and -5,7-dicarboxylic Acids as New Building Blocks for Anion Receptors. Chem. Eur. J. 2008, 14, 838-846. [CrossRef] [PubMed]

32. Zieliński, T.; Dydio, P.; Jurczak, J. Synthesis, structure and the binding properties of the amide-based anion receptors derived from 1H-indole-7-amine. Tetrahedron 2008, 64, 568-574. [CrossRef]

33. Niedbała, P.; Majdecki, M.; Dabbrowa, K.; Jurczak, J. Selective Carboxylate Recognition Using Urea-Functionalized Unclosed Cryptands: Mild Synthesis and Complexation Studies. J. Org. Chem. 2020, 85, 5058-5064. [CrossRef] [PubMed]

34. Niedbała, P.; Jurczak, J. One-Pot Parallel Synthesis of Unclosed Cryptands-Searching for Selective Anion Receptors via Static Combinatorial Chemistry Techniques. ACS Omega 2020, 5, 26271-26277. [CrossRef]

35. Dabbrowa, K.; Niedbała, P.; Pawlak, M.; Lindner, M.; Ignacak, W.; Jurczak, J. Tuning Anion-Binding Properties of 22-Membered Unclosed Cryptands by Structural Modification of the Lariat Arm. ACS Omega 2020, 5, 29601-29608. [CrossRef] 
36. Niedbała, P.; Jurczak, J. Effective synthetic strategy towards highly selective macrocyclic anion receptors based on static combinatorial chemistry. Tetrahedron 2020, 76, 131693. [CrossRef]

37. Maeda, H.; Haketa, Y.; Nakanishi, T. Aryl-Substituted $\mathrm{C}_{3}$-Bridged Oligopyrroles as Anion Receptors for Formation of Supramolecular Organogels. J. Am. Chem. Soc. 2007, 129, 13661-13764. [CrossRef] [PubMed]

38. Mazik, M.; Sonnenberg, C. Isopropylamino and Isobutylamino Groups as Recognition Sites for Carbohydrates: Acyclic Receptors with Enhanced Binding Affinity toward $\beta$-Galactosides. J. Org. Chem. 2010, 75, 6416-6423. [CrossRef] [PubMed]

39. Oh, J.; Hong, J. Molecular Recognition of Pyrophosphate with Extended Bis(Zn(II)-DPA) Derivatives. J. Org. Chem. 2019, 84, 15797-15804. [CrossRef]

40. Gale, P.A.; Hiscock, J.R.; Moore, S.J.; Caltagirone, C.; Hursthouse, M.B.; Light, M.E. Anion-Anion Proton Transfer in Hydrogen Bonded Complexes. Chem. Asian J. 2010, 5, 555-561. [CrossRef]

41. Cholewiak, A.; Tycz, A.; Jurczak, J. 8-Propyldithieno[3,2-b:2', $\left.3^{\prime}-e\right]$ pyridine-3,5-diamine (DITIPIRAM) Derivatives as Neutral Receptors Tailored for Binding of Carboxylates. Org. Lett. 2017, 19, 3001-3004. [CrossRef] [PubMed]

42. Rodríguez-Barrientos, D.; Rojas-Hernández, A.; Gutiérrez, A.; Moya-Hernández, R.; Gómez-Balderas, R.; Ramírez-Silva, M.T. Determination of $\mathrm{pK}_{\mathrm{a}}$ values of tenoxicam from ${ }^{1} \mathrm{H}-\mathrm{NMR}$ chemical shifts and of oxicams from electrophoretic mobilities (CZE) with the aid of programs SQUAD and HYPNMR. Talanta 2009, 80, 754-762. [CrossRef]

43. Dodziuk, H. Rigidity versus flexibility. A review of experimental and theoretical studies pertaining to the cyclodextrin nonrigidity. J. Mol. Struct. 2002, 614, 33-45. [CrossRef]

44. Zhao, Y.; Truhlar, D.G. The M06 suite of density functionals for main group thermochemistry, thermochemical kinetics, noncovalent interactions, excited states, and transition elements: Two new functionals and systematic testing of four M06-class functionals and 12 other functionals. Theor. Chem. Acc. 2008, 120, 215-241. [CrossRef]

45. Kozuch, S.; Martin, J.M.L. Halogen Bonds: Benchmarks and Theoretical Analysis. J. Chem. Theory Comput. 2013, 9, $1918-1931$. [CrossRef] [PubMed]

46. Bauzá, A.; Alkorta, I.; Frontera, A.; Elguero, J. On the Reliability of Pure and Hybrid DFT Methods for the Evaluation of Halogen, Chalcogen, and Pnicogen Bonds Involving Anionic and Neutral Electron Donors. J. Chem. Theory Comput. 2013, 9, 5201-5210. [CrossRef]

47. Dey, K.R.; Wong, B.M.; Hossain, M.A. Rational design of a macrocycle-based chemosensor for anions. Tetrahedron Lett. 2010, 51, 1329-1332. [CrossRef] [PubMed]

48. Hohenstein, E.G.; Chill, S.T.; Sherrill, C.D. Assessment of the Performance of the M05-2X and M06-2X Exchange-Correlation Functionals for Noncovalent Interactions in Biomolecules. J. Chem. Theory Comput. 2008, 4, 1996-2000. [CrossRef] [PubMed] 